\title{
EDITORIAL
}

\section{Effect-directed analysis (EDA) in aquatic ecotoxicology: state of the art and future challenges}

\author{
Markus Hecker • Henner Hollert
}

Received: 18 July 2009 / Accepted: 20 July 2009 / Published online: 25 August 2009

(C) Springer-Verlag 2009

\section{Background, aim, and scope}

One of the key challenges environmental toxicologists and risk assessors are facing is the characterization and assessment of the complex exposure scenarios that are typical for many environments we wish to protect. During the early days of ecotoxicology, it became obvious that the sole use of classic chemical-analytical techniques is not suitable of addressing this issue. Specifically, analysis of the vast number of chemicals typically present in an environmental sample would not only be prohibitively expensive but simply impossible due to limits in the available analytical methodologies for many chemicals - especially as often no a priori knowledge of the chemicals exists which are present in the sample. Therefore, approaches have been developed supplementing chemical analysis with bio-analytical techniques that make use of the specific properties of specific groups of chemicals to interfere with specific biological processes. This type of analysis has been coined effect-directed analysis (EDA) and is based on a combination of fractionation procedures, bio-testing, and subsequent chemical analyses (Brack 2003; Brack et al. 2003; Samoiloff et al. 1983; Schuetzle and Lewtas 1986).

In the late 1980s, one of the first standardized EDA procedures, namely the toxicity identification and evaluation

\footnotetext{
M. Hecker $(\bowtie)$

ENTRIX, Inc., Toxicology Centre, University of Saskatchewan,

44 Campus Drive,

Saskatoon SK S7N 5B3, Canada

e-mail: MHecker@Entrix.com

H. Hollert $(\bowtie)$

Institute for Environmental Research (Biology V),

Department for Ecosystem Analysis, RWTH Aachen University,

52074 Aachen, Germany

e-mail: Henner.Hollert@bio5.rwth-aachen.de
}

(TIE) approach, had been established by the US-EPA. This approach focuses primarily on the identification and evaluation of organic or inorganic contaminants in aqueous samples and is characterized by the following three steps (reviewed in Brack 2003):

1. Toxicity characterization by assignment of toxicity to general groups of toxicants (typically bioassay-directed analysis).

2. Identification of suspected toxicants (chemical analytical determination).

3. Confirmation of the suspected cause of toxicity.

While approaches like US-EPA's TIE have been an important step towards improving environmental risk assessment focusing on surface waters, it has increasingly been recognized that particle-bound contaminants (e.g., in suspended matter or sediments) may be of greater ecotoxicological relevance with respect to moderately or strongly lipophilic compounds. Especially sediments represent important long-term sinks for many toxicants (Apitz 2008; Brils et al. 2007; Bunge et al. 2007; Chen and White 2004; Forstner and Salomons 2008; Karlsson et al. 2008; Kase et al. 2008; Keiter et al. 2006), which can become bioavailable through flood events or benthic or bottomdwelling organisms (Babek et al. 2008; Gerbersdorf et al. 2007; Hilscherova et al. 2007; Schulze et al. 2007; Wolz et al. 2009). Consequently, there has been an increasing awareness of the relevance of particle-bound contaminants in the environment, an aspect that has not been considered satisfactorily in classic EDA approaches. In response to these concerns, there are now efforts on the way to establish EDA procedures for

- the assessment of sediment-related pollution such as the recently introduced TIE approach by the US-EPA, 
- the identification of harmful substances in sediments using resins and acute whole sediment assays (Phillips et al. 2009), or

- the EDA approaches for the identification of organic pollutants as reviewed by Brack (2003).

The aim of this editorial is to briefly review these recent developments, focusing on the need of rethinking current EDA approaches to address both existing and emerging toxicological issues related to sediments.

\section{The EDA process}

Effect-directed analysis aims to identify causative agents in complex mixtures through sequential bioassay and analytical chemical analyses (Fig. 1). Specifically, a complex sample (e.g., sediment, air particulate matter, or soil extract) is first analyzed using one (for specific questions such as the characterization of dioxin-like chemicals) or a combination of multiple (non-target analysis) bioassays representing different modes of biological action. Parallel to the assessment of effects on specific biological processes, the general toxicity of a sample (e.g., cytotoxicity for a cell-based bioassay) that could mask a specific response is evaluated. If a sample has been identified as having a significantly altered biological activity, it will then be subjected to fractionation, separating the chemicals contained in it by, e.g., polarity, molecular weight, or any other physical-chemical properties or combinations thereof (Brack 2003). Thereupon, these fractions are again analyzed for their potential to interfere with biological processes using both acute and mechanism-specific bioassays. This procedure is repeated until the activity can be pinpointed to one or multiple specific fractions that contain chemicals of specific

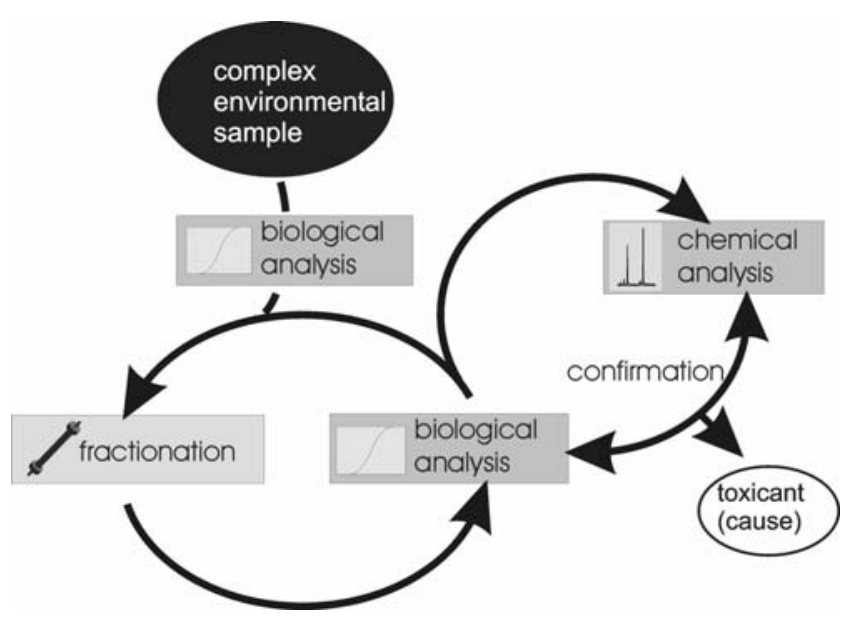

Fig. 1 Principle of effect-directed identification of toxicants (redrawn from Brack 2003) properties. Then these fractions are subjected to chemical analysis for suspected compounds.

Subsequently, in a mass-balance analysis, it will be assessed whether the chemically determined potency of a fraction can explain the biological responses observed in the bioassay (Keiter et al. 2008; Khim et al. 1999a, b). Mass-balance estimates of all major compounds contributing to the observed effects can be calculated to elucidate if all of the activity has been identified, and to assess the potential for interactions such as synergism or antagonism among contaminants present in the complex mixtures (Hilscherova et al. 2000; Korner et al. 2000). This strategy has been widely used for dioxin-like compounds (Safe 1990; Van den Berg et al. 1998), and has recently been adopted for estrogenic chemicals (Hilscherova et al. 2000; Hollert et al. 2005; Khim et al. 1999c; Korner et al. 2000). Finally, a confirmation step in the EDA procedure evaluates how much of the observed toxicity in the environmental sample can be attributed to the mixture of identified toxicants (Brack 2003). More recent approaches focus on the development of methodologies aiming at the assessment of mixture toxicity accounting for unknown modes of action and heterogeneity of concentration-response curves (Brack et al. 2008b).

\section{Current EDA approaches and their limitations}

Environmental exposure assessments using EDA are routinely used for a number of different chemical effect groups including dioxin-like, genotoxic, or estrogenic compounds. For example, bioassays such as the rat hepatoma cell-line H4IIE test or EROD induction in RTL-W1 cells are widely used to assess the exposure to dioxin-like chemicals that bind to the aryl hydrocarbon receptor (AhR) (Brack et al. 2005b, 2008a; Engwall et al. 1999; Hollert et al. 2002; Kammann et al. 2005b; Olsman et al. 2007b). However, often the chemically detected dioxin-like equivalents $(2,3,7,8$-TCDD equivalents $=$ TEQs) cannot explain the biological activity measured with the bioassay (bio-TEQ) (e.g., Brack et al. 2005b, 2008a). Similarly, attempts to correlate genotoxicity of complex environmental samples measured by tests such as the Ames, the micronucleus, or the comet assay with PAH concentrations often fail (Broman et al. 1994; Gustavsson et al. 2007; Kosmehl et al. 2004; Reifferscheid et al. 2008; Vahl et al. 1997), suggesting a contribution of other nonregulated mutagens to the observed biological effect. In a number of studies assessing sediments by EDA, it could be demonstrated, for example, that in addition to priority pollutants several non-regulated PAHs, including perylene and benzo[a]fluoranthene, $11 \mathrm{H}$-indeno[2,1,7-cde]pyrene, a methylbenzo[e]pyrene, and a methyl perylene were 
present at significant concentrations in the analyzed samples (Brack et al. 2005b). Furthermore, Fernandéz et al. (1992) showed that more polar compounds, including several polycyclic quinones and nitroquinones, as well as nitro-PAHs, contributed significantly to the mutagenic effects of marine sediments.

During the past two decades, significant attempts have been made to detect estrogenic effects in European surface waters, and to link them to the contamination with specific groups of chemicals (reviewed in Brack et al. 2007). However, in contrast to dioxin-like potentials, only few studies determined the relative contribution of individual chemicals analytically determined in a complex environmental sample or extract to its biological activity. By means of bioassay-directed fractionation using estrogen-sensitive systems such as MVLN or MCF7-luc cells, it could be demonstrated that the concentrations of the endogenous estrogen $17 \beta$-estradiol and the synthetic estrogen ethinylestradiol represented between $88 \%$ and $99.5 \%$ of the total estrogen equivalents in water samples from certain areas (Snyder et al. 2001). However, other studies revealed that synthetic chemicals such as alkylphenolic compounds can account for the majority of the estrogenic potential of a sample (Hollert et al. 2005; Khim et al. 1999b; Routledge et al. 1998; Sheahan et al. 2002). One of the key challenges for the assessment of the contribution of individual chemicals to the bioassay derived estrogenic potential (estradiol equivalents=EEQs) of a sample is the sensitivity of the utilized analytical method, as has been demonstrated by a study assessing estrogenic compounds in complex environmental samples in the catchment area of the River Neckar, Germany (Hollert et al. 2005). Those estrogenic chemicals that were detected at concentrations above the method detection limits, including nonyl- and octylphenol, phthalates, PCBs, bisphenol A, and DDT, were only able to explain $9 \%$ to $14 \%$ of the total Bio-EEQs. In contrast, when the method detection limits of chemicals that could not be detected by the utilized analytical methods, namely $17 \beta$ estradiol and ethinylestradiol, were taken as a basis of estimation for the Bio-EEQs, 95\% of the Chem-EEQ could be explained. Advanced analytical methods for natural and synthetic hormones with lower detection limits are one way to reduce this problem (Aerni et al. 2004, Brack et al. 2007).

While the concept of EDA is increasingly utilized in hazard assessment, often these studies focus on a specific endpoint and are limited in scope (Brack et al. 2005a, 2007; Hollert et al. 2009a; von der Ohe et al. 2009). However, as recently suggested, EDA may be used as additional line of evidence in comprehensive weight-of-evidence studies (Chapman and Hollert 2006), aiming at the identification of the unknown substances responsible for the biological effects in the bioassay under elucidation of the ecological relevance (Fig. 2).

Within the last decade, increasingly, attempts were made to improve EDA approaches, e.g., by including fractionation methods for more polar compounds (Lubcke-von Varel et al. 2008; Meinert et al. 2007), methods for addressing the bioavailability within the fractionation approach (Bandow et al. 2009; Schwab and Brack 2007), incorporating structure generation and mass spectral classifiers for identifying of unknown substances (Schymanski et al. 2008), and the use of additional biological endpoints, such as gene expression alterations (Scholz et al. 2008), teratogenicity, and genotoxicity (Kosmehl et al. 2007), and steroidogenesis (Hecker et al. 2007). One particular topic that has concerned risk assessors and regulator during the past two decades is the issue of endocrine disruption. While a large number of national or international programs exist that use a variety of standardized or validated tests to screen chemicals for the Endocrine Disruption properties, such assays are rarely used environmental monitoring or ERA. Specifically,
Fig. 2 Although the sediment triad approach is able to gain comprehensive insights into the contamination, the biological effects in bioassays, and alterations in community structure, it often fails in identifying the chemicals responsible for adverse effects. A combination of the triad approach with together with EDA is a promising conceptual framework to overcome this shortcoming (Chapman and Hollert 2006)

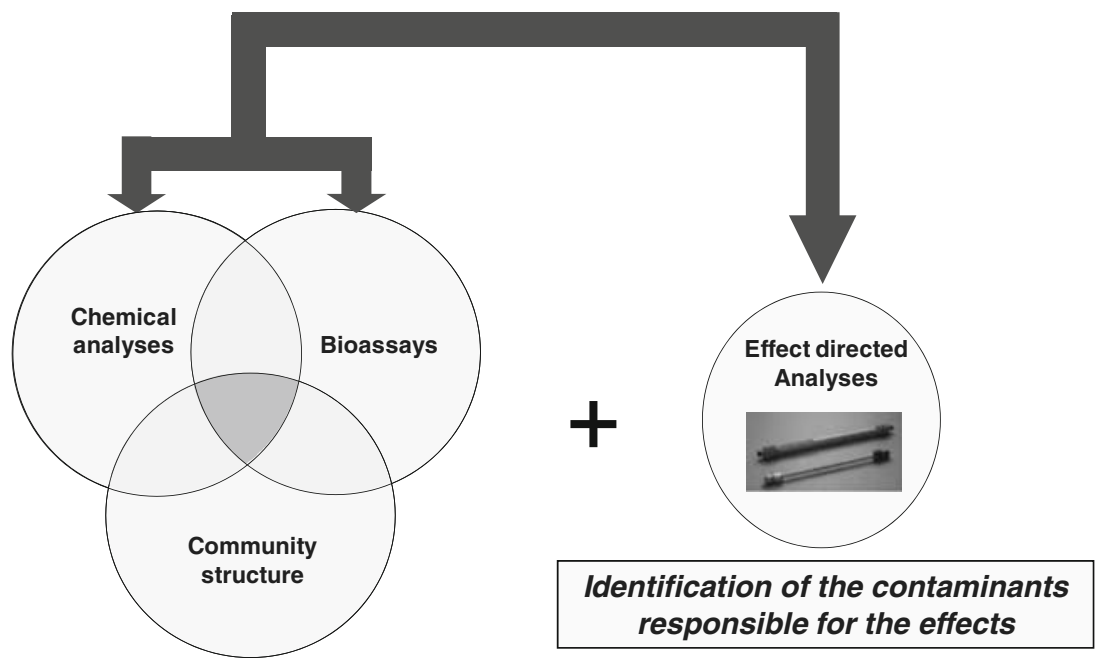


these include the potential of chemicals to interact with the nuclear sex hormone receptors (estrogen and androgen receptor) or to affect the synthesis of steroid hormones. Recent studies have demonstrated, however, that some of these assays such as the L-YES (Wagner and Oehlmann 2009) and the H295R Steroidogenesis Assay (Gracia et al. 2008; Grund et al. 2009; Hecker et al. 2007; Hecker and Giesy 2008) have very great promise as biotests in support of EDA of complex environmental samples. Initial studies with sediments and sewage treatment plant effluents have revealed differential effects when using a combination of different bioassays that capture estrogenic, steroidogenic, dioxin-like, mutagenic/genotoxic and teratogenic effects, fractionation, and chemical analysis, demonstrating the necessity of holistic screening approaches.

Also, there are increasing concerns about emerging contaminants including endocrine disrupting chemicals (Oehlmann et al. 2009; Vos et al. 2000), perfluorinated compounds (Giesy and Kannan 2002; Jernbro et al. 2007), as well as polybrominated and mixed halogenated dibenzo$p$-dioxins and -furans (Olsman et al. 2007a). For these compounds, no or only a limited number of sufficiently specific bioassays are available, and thus, such exposures often cannot be appropriately addressed. As a consequence, there is still a great need for refinement and standardization of current sediment EDA approaches that allow capturing and assessing exposures to these chemicals. While well established for its use in ERA of contaminants such as dioxin-like, genotoxic/mutagenic, or estrogenic substances, the continuing discovery of new contaminant groups of concern in the environment or new effect types pose new challenges to classical EDA approaches. These challenges include establishing of bioassays that are specific to the biological activity of chemical groups of concern, as well as the identification and description of relative potencies to model compounds characteristic for these types of effects to enable the utilization of mass-balance approaches.

Finally, as shown in several studies, assessing crude extracts by means of cell-based bioassays may be limited due to general (cyto)toxicity that can mask mechanismspecific effects (Brack et al. 2005b; Hollert et al. 2002; Kammann et al. 2005b). In these situations, the issue of overlying toxicity in the crude extract can be overcome by fractionation approaches resulting in a separation of compounds with different modes of actions.

\section{Use of EDA in environmental risk assessment}

Effect-directed analysis has been shown to have the potential as a powerful tool in support of environmental risk assessment (ERA), and already is routinely utilized in environmental monitoring programs (Biselli et al. 2005;
Brack et al. 2005a, 2007; Kammann et al. 2005a; Phillips et al. 2009; von der Ohe et al. 2009; Weiss et al. 2009; Wölz et al. 2008). With respect to comprehensive toxicological assessments of freshwater systems, the EDA approach was used in several case studies investigating whole catchment areas, providing evidence on the main stressors and possible mitigation measures in order to improve the ecological status of river ecosystems (Brack et al. 2005a, 2007, 2008a; Hollert et al. 2009a; Keiter et al. 2006, 2008, 2009a, b; Weiss et al. 2009). However, to date EDA is almost exclusively based on measurable effects in in vitro and in vivo biotests. Therefore, to address current needs of regulators and risk assessors, an increasing focus should be on the integration of EDA into ERA. Specifically, there is need for the development of tools to confirm EDA-determined key toxicants as stressors in populations, communities, and ecosystems (Brack et al. 2007). One of the most important steps towards these goals is the advancement of toxicant identification approaches/technologies to aid in the identification of unknown substances that are often driving the bioanalytically derived potentials of a sample as discussed in the previous chapter. The development of such tools and strategies represents a challenging task for the next years, but will be an important step forward regarding the successful implementation of national and international environmental programs such as the European Water Framework Directive. They will not only provide evidence on the main stressors responsible for an observed effect but also allow to focus on possible mitigation measures in order to improve the ecological status of an ecosystem.

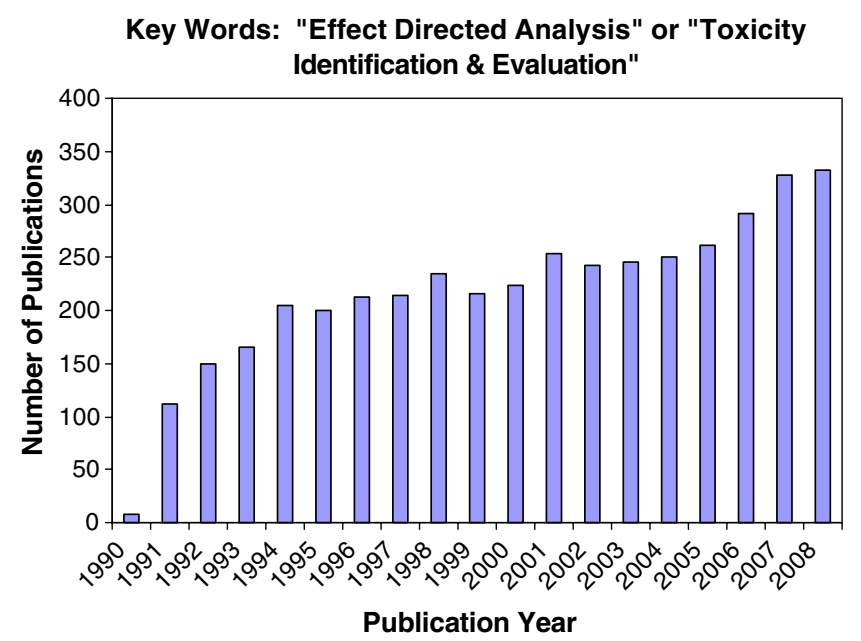

Fig. 3 Number of articles published between 1990 and 2008 containing the key words "Effect Directed Analysis" and/or "Toxicity Identification \& Evaluation". Source: ISI Web of Knowledge, July 2009 


\section{Conclusions}

The current focus of research in the field of EDA, as demonstrated by the significant increase in publications (series) regarding this topic (Fig. 3), emphasizes its relevance in the area of environmental sciences, specifically in ERA. For example, a series of articles has been published in the German language journal Umweltwiss Schadst Forsch addressing different issues of effect-directed analysis (Brack et al. 2009; Hollert et al. 2009a, b; Reifferscheid et al. 2009; Schwarzbauer et al. 2009). In addition, a number of reviews presenting the outcome of the integrated EU project MODELKEY - which aimed at using different integrated bio-analytical approaches as well as a comprehensive EDA framework for developing a sound ERA strategy for European freshwater systems (Brack et al. 2005a) - will be published in the forthcoming issues of Environ Sci Pollut Res. With this editorial, we wish to further underline the importance of combining chemical and toxicological methods as well as the need for more emphasis on the further development of effectdirected analysis approaches and their application in ERA. It is our goal to encourage scientists to submit both research papers and reviews on current research, advancements, and future needs, in context with the effect-directed analysis approach. Finally, we wish to strongly recommend to national and international agencies, organizations, and regulatory bodies the need to financially support basic and interdisciplinary research towards further development and application of effect-directed analysis. The ultimate goal is to provide advanced tools for more effective, economic, and safe ERA (Schaeffer et al. 2009).

\section{References}

Aerni HR, Kobler B, Rutishauser BV, Wettstein FE, Fischer R, Giger W, Hungerbuhler A, Marazuela MD, Peter A, Schonenberger R, Vogeli AC, Suter MJ, Eggen RI (2004) Combined biological and chemical assessment of estrogenic activities in wastewater treatment plant effluents. Anal Bioanal Chem 378:688-696

Apitz SE (2008) Adaptive management principles and sediment management. J Soils Sediments 8:359-362

Babek O, Hilscherova K, Nehyba S, Zeman J, Famera M, Francu J, Holoubek I, Machat J, Klanova J (2008) Contamination history of suspended river sediments accumulated in oxbow lakes over the last 25 years. J Soils Sediments 8:165-176

Bandow N, Altenburger R, Lubcke-von Varel U, Paschke A, Streck G, Brack W (2009) Partitioning-based dosing: an approach to include bioavailability in the effect-directed analysis of contaminated sediment samples. Environ Sci Technol 43:3891-3896

Biselli S, Reineke N, Heinzel N, Kammann U, Franke S, Huhnerfuss H, Theobald N (2005) Bioassay-directed fractionation of organic extracts of marine surface sediments from the North and Baltic Sea-Part I: determination and identification of organic pollutants. J Soils Sediments 5:171-181
Brack W (2003) Effect-directed analysis: a promising tool for the identification of organic toxicants in complex mixtures? Anal Bioanal Chem 377:397-407

Brack W et al (2005a) MODELKEY. Models for assessing and forecasting the impact of environmental key pollutants on freshwater and marine ecosystems and biodiversity. Environ Sci Pollut Res Int 12:252-256

Brack W, Erdinger L, Schirmer K, Hollert H (2005b) Effect-directed analysis of mutagens and ethoxyresorufin-o-deethylase inducers in aquatic sediments. Environ Toxicol Chem 24:2445-2458

Brack W, Klamer HJ, Lopez de Alda M, Barcelo D (2007) Effectdirected analysis of key toxicants in European river basins a review. Environ Sci Pollut Res Int 14:30-38

Brack W, Kind T, Hollert H, Schrader S, Moder M (2003) Sequential fractionation procedure for the identification of potentially cytochrome P4501A-inducing compounds. J Chromatogr A 986:55-66

Brack W, Bandow N, Schwab K, Schulze T, Streck G (2009) Identifizierung toxischer verbindungen in sedimenten: ansätze zur integration von wirkung und bioverfügbarkeit. Umweltwiss Schadst Forsch 21:240-244

Brack W, Blaha L, Giesy JP, Grote M, Moeder M, Schrader S, Hecker M (2008a) Polychlorinated naphthalenes and other dioxin-like compounds in Elbe River sediments. Environ Toxicol Chem 27:519-528

Brack W, Schmitt-Jansen M, Machala M, Brix R, Barcelo D, Schymanski E, Streck G, Schulze T (2008b) How to confirm identified toxicants in effect-directed analysis. Anal Bioanal Chem 390:1959-1973

Brils J et al (2007) Sediment management: an essential element of river basin management plans. J Soils Sediments 7:117-132

Broman D, Näf C, Rannug U (1994) Mutagenic effect of extracts from particular matter collected with sediment traps in the archipelago of Stockholm and the open northern Baltic. Bull Environ Contam Toxicol 53:669-674

Bunge M, Kahkonen MA, Ramisch W, Opel M, Vogler S, Walkow F, Salkinoia-Salonen M, Lechner U (2007) Biological activity in a heavily organohalogen-contaminated river sediment. Environ Sci Pollut Res 14:3-10

Chapman PM, Hollert H (2006) Should the sediment quality triad become a tetrad, a pentad, or possibly even a hexad? J Soils Sediments 6:4-8

Chen GS, White PA (2004) The mutagenic hazards of aquatic sediments: a review. Mutat Res Rev Mutat Res 567:151-225

Engwall M, Brunstrom B, Naf C, Hjelm K (1999) Levels of dioxinlike compounds in sewage sludge determined with a bioassay based on EROD induction in chicken embryo liver cultures. Chemosphere 38:2327-2343

Fernandéz R, Grifoll PM, Sonas AM, Bayona JM, Albaiges J (1992) Bioassay-directed chemical analysis of genotoxic components in coastal sediments. Environ Sci Technol 26:817-829

Forstner U, Salomons W (2008) Trends and challenges in sediment research 2008: the role of sediments in river basin management. J Soils Sediments 8:281-283

Gerbersdorf SU, Jancke T, Westrich B (2007) Sediment properties for assessing the erosion risk of contaminated riverine sites. J Soils Sediments 7:25-35

Giesy JP, Kannan K (2002) Perfluorochemical surfactants in the environment. Environ Sci Technol 36:146A-152A

Gracia T, Jones PD, Higley EB, Hilscherova K, Newsted JL, Murphy MB, Chan AKY, Zhang XW, Hecker M, Lam PKS, Wu RSS, Giesy JP (2008) Modulation of steroidogenesis by coastal waters and sewage effluents of Hong Kong, China, using the H295R assay. Environ Sci Pollut Res 15:332-343

Grund S, Higley E, Schönberger R, Suter M, Giesy JP, Braunbeck T, Hecker M, Hollert H (2009) Assessment of the endocrine 
disrupting potential of sediments from the Upper Danube River (Germany) using a battery of in vitro bioassays and chemical analysis. Aquat Toxicol (in press)

Gustavsson L, Hollert H, Jonsson S, van Bavel B, Engwall M (2007) Reed beds receiving industrial sludge containing nitroaromatic compounds. Effects of outgoing water and bed material extracts in the umu-c genotoxicity assay, DR-CALUX assay and on early life stage development in zebrafish (Danio rerio). Environ Sci Pollut Res Int 14:202-211

Hecker M, Giesy JP (2008) Novel trends in endocrine disruptor testing: the H295R Steroidogenesis Assay to identify inducers and inhibitors of hormone production. Anal Biochem Chem 390:287-291

Hecker M, Hollert H, Cooper R, Vinggaard AM, Akahori Y, Murphy M, Nellemann C, Higley E, Newsted J, Wu R, Lam P, Laskey J, Buckalew A, Grund S, Nakai M, Timm G, Giesy J (2007) The OECD validation program of the H295R steroidogenesis assay for the identification of in vitro inhibitors and inducers of testosterone and estradiol production. Phase 2: inter-laboratory pre-validation studies. Environ Sci Pollut Res 14:23-30

Hilscherova K, Machala M, Kannan K, Blankenship AL, Giesy JP (2000) Cell bioassays for detection of aryl hydrocarbon (AhR) and estrogen receptor (ER) mediated activity in environmental samples. Environ Sci Pollut Res 7:159-171

Hilscherova K, Dusek L, Kubik V, Cupr P, Hofman J, Klanova J, Holoubek I (2007) Redistribution of organic pollutants in river sediments and alluvial soils related to major floods. J Soils Sediments 7:167-177

Hollert H, Durr M, Holtey-Weber R, Islinger M, Brack W, Farber H, Erdinger L, Braunbeck T (2005) Endocrine disruption of water and sediment extracts in a non-radioactive dot blot/RNAse protection-assay using isolated hepatocytes of rainbow trout. Environ Sci Pollut Res Int 12:347-360

Hollert H, Hudjetz S, Claus E, Manz W, Reifferscheid G, Heininger P, Schwarzbauer J, Ahlf W, Braunbeck T, Brack W, Schulze T, Schäffer A, Ratte H-T (2009a) Über die Notwendigkeit der wirkungsorientierten Analytik in einer umfassenden Wasserforschung. Umweltwiss Schadst Forsch 21:235-237

Hollert H, Bluhm K, Keiter S, Böttcher M, Grund S, Seitz N, Otte J, Braunbeck T, Hecker M, Higley E, Giesy J, Takner H, van Bavel B, Engwall M, Reifferscheid G, Manz W, Erdinger L, Schulze T, Luebcke-van Varel U, Brack W, Kammann U, Schöneberger R, Suter M, Strähle U (2009b) Eine weight-ofevidence-studie zur bewertung der sedimentbelastung und des fischrückgangs in der oberen donau. Umweltwiss Schadst Forsch 21:260-263

Hollert N, Durr M, Olsman H, Halldin K, van Bavel E, Brack W, Tysklind M, Engwall M, Braunbeck T (2002) Biological and chemical determination of dioxin-like compounds in sediments by means of a sediment triad approach in the catchment area of the river Neckar. Ecotoxicology 11:323-336

Jernbro S, Rocha PS, Keiter S, Skutlarek D, Farber H, Jones PD, Giesy JP, Hollert H, Engwall M (2007) Perfluorooctane sulfonate increases the genotoxicity of cyclophosphamide in the micronucleus assay with V79 cells. Further proof of alterations in cell membrane properties caused by PFOS. Environ Sci Pollut Res Int $14: 85-87$

Kammann U, Lang T, Vobach M, Wosniok W (2005a) Ethoxyresorufin- $O$-deethylase (EROD) activity in dab (Limanda limanda) as biomarker for marine monitoring. Environ Sci Pollut Res 12:140-145

Kammann U, Biselli S, Reineke N, Wosniok W, Danischewski D, Huhnerfuss H, Kinder A, Sierts-Herrmann A, Theobald N, Vahl HH, Vobach M, Westendorf J, Steinhart H (2005b) Bioassaydirected fractionation of organic extracts of marine surface sediments from the North and Baltic Sea-Part II: results of the biotest battery and development of a biotest index. J Soils Sediments 5:225-232

Karlsson J, Sundberg H, Akerman G, Grunder K, Eklund B, Breitholtz M (2008) Hazard identification of contaminated sites-ranking potential toxicity of organic sediment extracts in crustacean and fish. J Soils Sediments 8:263-274

Kase R, Hansen PD, Fischer B, Manz W, Heininger P, Reifferscheid G (2008) Integral assessment of estrogenic potentials of sedimentassociated samples-Part 1: the influence of salinity on the in vitro tests ELRA, E-Screen and YES. Environ Sci Pollut Res 15:75-83

Keiter S, Böttcher M, Grund S, Seitz N, Braunbeck T, Hollert H (2009a) Der fischrückgang in der oberen donau. Umweltwiss Schadst Forsch 21:186-196

Keiter S, Braunbeck T, Heise S, Pudenz S, Manz W, Hollert H (2009b) A fuzzy logic-classification of sediments based on data from in vitro biotests. J Soils Sediments 9:168-179

Keiter S, Rastall A, Kosmehl T, Wurm K, Erdinger L, Braunbeck T, Hollert H (2006) Ecotoxicological assessment of sediment, suspended matter and water samples in the upper Danube River. A pilot study in search for the causes for the decline of fish catches. Environ Sci Pollut Res Int 13:308-319

Keiter S, Grund S, van Bavel B, Hagberg J, Engwall M, Kammann U, Klempt M, Manz W, Olsman H, Braunbeck T, Hollert H (2008) Activities and identification of aryl hydrocarbon receptor agonists in sediments from the Danube river. Anal Bioanal Chem 390:2009-2019

Khim JS, Kannan K, Villeneuve DL, Koh CH, Giesy JP (1999a) Characterization and distribution of trace organic contaminants in sediment from Masan Bay, Korea. 1. Instrumental analysis. Environ Sci Technol 33:4199-4205

Khim JS, Villeneuve DL, Kannan K, Koh CH, Giesy JP (1999b) Characterization and distribution of trace organic contaminants in sediment from Masan Bay, Korea. 2. In vitro gene expression assays. Environ Sci Technol 33:4206-4211

Khim JS, Villeneuve DL, Kannan K, Lee KT, Snyder SA, Koh CH, Giesy JP (1999c) Alkylphenols, polycyclic aromatic hydrocarbons, and organochlorines in sediment from Lake Shihwa, Korea: instrumental and bioanalytical characterization. Environ Toxicol Chem 18:2424-2432

Korner W, Bolz U, Sussmuth W, Hiller G, Schuller W, Hanf V, Hagenmaier H (2000) Input/output balance of estrogenic active compounds in a major municipal sewage plant in Germany. Chemosphere 40:1131-1142

Kosmehl T, Krebs F, Manz W, Braunbeck T, Hollert H (2007) Differentiation between bioavailable and total hazard potential of sediment-induced DNA fragmentation as measured by the comet assay with zebrafish embryos. J Soils Sediments 7: 377-387

Kosmehl T, Krebs F, Manz W, Erdinger L, Braunbeck T, Hollert H (2004) Comparative genotoxicity testing of Rhine river sediment extracts using the permanent cell lines RTG-2 and RTL-W1 in the comet assay and Ames assay. J Soils Sediments 4:84-94

Lubcke-von Varel U, Streck G, Brack W (2008) Automated fractionation procedure for polycyclic aromatic compounds in sediment extracts on three coupled normal-phase highperformance liquid chromatography columns. J Chromatogr A $1185: 31-42$

Meinert C, Moeder M, Brack W (2007) Fractionation of technical p-nonylphenol with preparative capillary gas chromatography. Chemosphere 70:215-223

Oehlmann J, Schulte-Oehlmann U, Kloas W, Jagnytsch O, Lutz I, Kusk KO, Wollenberger L, Santos EM, Paull GC, Van Look KJW, Tyler CR (2009) A critical analysis of the biological impacts of plasticizers on wildlife. Philos Trans R Soc B Biol Sci 364:2047-2062 
Olsman H, Schnurer A, Bjornfoth H, van Bavel B, Engwall M (2007a) Fractionation and determination of $\mathrm{Ah}$ receptor $(\mathrm{AhR})$ agonists in organic waste after anaerobic biodegradation and in batch experiments with PCB and decaBDE. Environ Sci Pollut Res 14:36-43

Olsman H, Engwall M, Kammann U, Klempt M, Otte J, Bavel B, Hollert H (2007b) Relative differences in aryl hydrocarbon receptor-mediated response for 18 polybrominated and mixed halogenated dibenzo-p-dioxins and -furans in cell lines from four different species. Environ Toxicol Chem 26:2448-2454

Phillips BM, Anderson BS, Hunt JW, Clark SL, Voorhees JP, Tjeerdema RS, Casteline J, Stewart M (2009) Evaluation of phase II toxicity identification evaluation methods for freshwater whole sediment and interstitial water. Chemosphere 74:648-653

Reifferscheid G, Buchinger S, Claus E (2009) Das Potenzial genetisch modifizierter und gentechnisch konstruierter Organismen in der wirkungsbezogenen Analytik. Umweltwiss Schadst Forsch 21:256-259

Reifferscheid G, Ziemann C, Fieblinger D, Dill F, Gminski R, Grummt HJ, Hafner C, Hollert H, Kunz S, Rodrigo G, Stopper H, Selke D (2008) Measurement of genotoxicity in wastewater samples with the in vitro micronucleus test: results of a roundrobin study in the context of standardisation according to ISO. Mutat Res 649:15-27

Routledge EJ, Sheahan D, Desbrow C, Brighty GC, Waldock M, Sumpter JP (1998) Identification of estrogenic chemicals in STW effluent. 2. In vivo responses in trout and roach. Environ Sci Technol 32:1559-1565

Safe S (1990) Polychlorinated biphenyls (PCBs), dibenzo-p-dioxins (PCDDs), dibenzofurans (PCDFs), and related compounds: environmental and mechanistic considerations which support the development of toxic equivalency factors (TEFs). Crit Rev Toxicol 21:51-88

Samoiloff MR, Bell J, Birkholz DA, Webster GRB, Arnott EG, Pulak R, Madrid A (1983) Combined bioassay-chemical fraction scheme for the determination and ranking of toxic chemicals in sediments. Environ Sci Technol 17:329-334

Schaeffer A, Hollert H, Ratte HT, Ross-Nickoll M, Filser J, Matthies M, Oehlmann J, Scheringer M, Schulz R, Seitz A (2009) An indispensable asset at risk: merits and needs of chemicals-related environmental sciences. Environ Sci Pollut Res 16:410-413

Scholz S, Fischer S, Gundel U, Kuster E, Luckenbach T, Voelker D (2008) The zebrafish embryo model in environmental risk assessment - applications beyond acute toxicity testing. Environ Sci Pollut Res Int 15:394-404

Schuetzle D, Lewtas J (1986) Bioassay-directed chemical analysis in environmental research. Anal Chem 58:1060A-1075A

Schulze T, Ricking M, Schroter-Kermani C, Korner A, Denner HD, Weinfurtner K, Winkler A, Pekdeger A (2007) The German Environmental Specimen Bank-sampling, processing, and archiving sediment and suspended particulate matter. J Soils Sediments 7:361-367

Schwab K, Brack W (2007) Large volume TENAX (R) extraction of the bioaccessible fraction of sediment-associated organic compounds for a subsequent effect-directed analysis. J Soils Sediments 7:178-186

Schwarzbauer J, Claus E, Heininger P, Neumann-Hensel H (2009) Effektorientierte untersuchungen zur algentoxizität fraktionierter porenwässer und eluate aus elbesedimenten. Umweltwiss Schadst Forsch 21:267-271

Schymanski EL, Meinert C, Meringer M, Brack W (2008) The use of MS classifiers and structure generation to assist in the identification of unknowns in effect-directed analysis. Anal Chim Acta 615:136-147

Sheahan DA, Brighty GC, Daniel M, Kirby SJ, Hurst MR, Kennedy J, Morris S, Routledge EJ, Sumpter JP, Waldock MJ (2002) Estrogenic activity measured in a sewage treatment works treating industrial inputs containing high concentrations of alkylphenolic compounds-a case study. Environ Toxicol Chem 21:507-514

Snyder SA, Villeneuve DL, Snyder EM, Giesy JP (2001) Identification and quantification of estrogen receptor agonists in wastewater effluents. Environ Sci Technol 35:3620-3625

Vahl HH, Karbe L, Westendorf J (1997) Genotoxicity assessment of suspended particulate matter in the Elbe river: comparison of Salmonella microsome test, arabinose resistance test, and umutest. Mut Res 394:81-93

Van den Berg $\mathrm{M}$ et al (1998) Toxic equivalency factors (TEFs) for PCBs, PCDDs, PCDFs for humans and wildlife, EROD. Environ Health Perspect 106:775-792

von der Ohe PC, De Deckere E, Pruss A, Munoz I, Wolfram G, Villagrasa M, Ginebreda A, Hein M, Brack W (2009) Toward an integrated assessment of the ecological and chemical status of European river basins. Integr Environ Assess Manag 5:50-61

Vos GJ, Dybing E, Greim HA, Ladefoged O, Lambré C, Tarazona JV, Brandt I, Vethaak AD (2000) Health effects of endocrinedisrupting chemicals on wildlife, with special reference to the European situation. Crit Rev Toxicol 30:71-133

Weiss JM, Hamers T, Thomas KV, van der Linden S, Leonards PE, Lamoree MH (2009) Masking effect of anti-androgens on androgenic activity in European river sediment unveiled by effect-directed analysis. Anal Bioanal Chem 394:1385-1397

Wagner M, Oehlmann J (2009) Endocrine disruptors in bottled mineral water: total estrogenic burden and migration from plastic bottles. Environ Sci Pollut Res 16:278-286

Wölz J, Engwall M, Maletz S, Olsman Takner H, van Bavel B, Kammann U, Klempt M, Weber R, Braunbeck T, Hollert H (2008) Changes in toxicity and Ah receptor agonist activity of suspended particulate matter during flood events at the rivers Neckar and Rhine - a mass balance approach using in vitro methods and chemical analysis. Environ Sci Pollut Res Int 15:536-553

Wolz J, Cofalla C, Hudjetz S, Roger S, Brinkmann M, Schmidt B, Schaffer A, Kammann U, Lennartz G, Hecker M, Schuttrumpf H, Hollert H (2009) In search for the ecological and toxicological relevance of sediment re-mobilisation and transport during flood events. J Soils Sediments 9:1-5 